\title{
Perbedaan Efektifitas Art therapy dan Brain gym terhadap Fungsi Kognitif dan Intelektual pada Lansia Demensia di BPSTW Yogyakarta
}

\author{
Rizky Erwanto ${ }^{1}$, Dwi Endah Kurniasih ${ }^{2}$ \\ ${ }^{1}$ Program Pendidikan Profesi Ners, Fakultas Ilmu Kesehatan, Universitas Respati Yogyakarta \\ ${ }^{2}$ Program Studi S1 Kesehatan Masyarakat, Fakultas Ilmu Kesehatan, Universitas Respati \\ Yogyakarta \\ Email: rizkyerwanto@gmail.com
}

Received 30 August 2018; Accepted 31 August 2018; Published 6 November 2018

\begin{abstract}
ABSTRAK
Daerah Istimewa Yogyakarta memiliki jumlah proporsi lansia tertinggi di Indonesia. Pertambahan usia dan peningkatan prevalensi penyakit tidak menular, merupakan faktor utama penyebab penurunan fungsi kognitif dan intelektual yang berdampak pada menurunnya aktivitas sosial sehari-hari pada lanjut usia. Berdasarkan masalah diatas, maka diperlukan upaya untuk mengatasi masalah demensia pada lansia. Upaya yang dapat dilakukan yaitu dengan memberikan art therapy dan brain gym. Tujuan dari penelitian adalah untuk mengetahui efektifitas intervensi art therapy dan brain gym terhadap fungsi kognitif dan intelektual pada lansia demensia. Jenis penelitian ini adalah penelitian ekperimen semu atau Quasi experimental. Penelitian ini menggunakan rancangan pre dan post without control group design. Berdasarkan hasil uji bivariate untuk menguji efektifitas brain gym terhadap fungsi kognitif dan intelektual menggunakan uji Wilcoxon signed rank test dengan $\mathrm{p}$ value sebesar 0,00 dan 0,018. Berdasarkan hasil uji bivariate untuk menguji efektifitas art therapy terhadap fungsi kognitif dan intelektual menggunakan uji Wilcoxon signed rank test dan paired t test dengan $\mathrm{p}$ value sebesar 0,00 dan 0,049 . Nilai $\mathrm{p}$ value $<0,05$, yang berarti bahwa art therapy dan brain gym efektif meningkatkan fungsi kognitif dan intelektual lansia demensia. Sedangkan hasil uji bivariate menggunakan uji MannWhitney untuk mengukur perbedaan skor fungsi kognitif dan intelektual pada kedua kelompok didapatkan hasil 0,158 dan 0,935. Nilai $p$ value $>0,05$, yang berarti bahwa tidak ada perbedaan pengaruh antara art therapy dan brain gym terhadap fungsi kognitif dan intelektual lansia demensia.
\end{abstract}

Kata Kunci: Art therapy, brain gym, fungsi kognitif dan intelektual, lansia demensia

Copyright (C) 2018 STIKes Surya Mitra Husada

All right reserved.

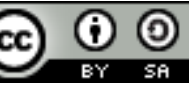

This is an open-acces article distributed under the terms of the Creative Commons AttributionShareAlike 4.0 International License.

\section{PENDAHULUAN}

Jumlah dan proporsi penduduk lanjut usia mengalami peningkatan. Populasi penduduk lanjut usia di dunia pada tahun 2015 sebanyak 901 juta jiwa dengan persentase 12,3\% dari seluruh populasi. Penduduk berusia 60 tahun keatas tumbuh 3,26\% tiap tahun. Indonesia merupakan negara dengan jumlah penduduk lanjut usia 8,9\% di dunia (United Nations Department of Economic and Social 
Affairs, 2015). Populasi penduduk lanjut usia di Indonesia pada tahun 2013 sebanyak 8,9\%, pada tahun 2050 diperkirakan meningkat menjadi $21,4 \%$, serta mengalami peningkatan pada tahun 2100 menjadi $41 \%$. Hasil proyeksi penduduk tahun 2010-2035, Indonesia memasuki periode lansia atau ageing. Propinsi yang mempunyai penduduk lansia dengan proporsi tertinggi adalah Propinsi Daerah Istimewa Yogyakarta (13,04 persen) (Kemenkes RI, 2016). Hal ini menjadikan Daerah Istimewa Yogyakarta termasuk daerah yang memasuki era penduduk berstruktur tua (aging structured population) karena jumlah penduduk yang berusia 60 tahun ke atas telah melebihi angka tujuh persen. Provinsi DI Yogyakarta memiliki Balai Sosial Tresna Werdha (BPSTW) sebagai lembaga pelayanan sosial lanjut usia berbasis Balai Pelayanan yang bertugas memberikan bimbingan dan pelayanan bagi lanjut usia terlantar agar dapat hidup secara baik dan terawat dalam kehidupan masyarakat.

Seiring dengan peningkatan jumlah lansia tersebut perlu mendapat perhatian dikarenakan lansia termasuk kelompok/populasi beresiko (population at risk) dan kelompok rentan (vulnerable population) (Stanhope \& Lancaster, 2004; Maurer \& Smith, 2005). Lansia sangat berkaitan dengan berbagai perubahan akibat proses menua seperti perubahan anatomi ataupun fisiologi, penyakit, keadaan patologik sebagai akibat penuaan, serta pengaruh psikososial pada fungsi organ (Darmojo, 2011).

Pertambahan usia dan peningkatan prevalensi penyakit tidak menular, merupakan faktor utama penyebab penurunan fungsi kognitif dan intelektual yang kelak akan meningkatkan penyakit Alzheimer dan demensia lainnya pada kelompok lanjut usia. Penurunan fungsi kognitif berdampak pada menurunnya aktivitas sosial sehari-hari pada lanjut usia yang menjadi problem dalam kesehatan masyarakat, dan berdampak pada bertambahnya pembiayaan keluarga, masyarakat dan pemerintah. Didunia jumlah lansia yang mengalami demensia sebanyak 4,6 juta kasus yang dilaporkan dan diprediksi pada tahun 2050 jumlah lansia penderita demensia di dunia mencapai 100 juta (Alzheimer Disease International, 2008). Penyakit Alzheimer adalah bentuk paling umum dari demensia dan dapat berkontribusi 60-70\% dari bentuk demensia yang lain. Pada tahun 2015, penderita demensia di dumia sebanyak 47 juta (atau sekitar 5\% dari populasi lansia di dunia), diperkirakan meningkat menjadi 75 juta pada tahun 2030 dan 132 juta pada tahun 2050. Di Indonesia, jumlah Orang Dengan Demensia (ODD) diperkirakan akan makin meningkat dari 960.000 di tahun 2013, menjadi 1.890.000 di tahun 2030 dan 3.980.000 ODD di tahun 2050 (World Alzheimer Report, 2012;Kemenkes, 2015). Prevalensi demensia lanjut usia umur 60 tahun atau lebih di DI Yogyakarta mencapai 20,1\%. Semakin meningkatnya umur maka tingkat prevalensi demensia juga meningkat. Pada umur 60 tahun 1 dari 10 lanjut usia DI Yogyakarta mengalami demensia. Memasuki usia 70an tahun 2 dari 10 lanjut usia yang terkena demensia. Ketika memasuki usia 80an tahun 4-5 dari 10 lanjut usia yang terkena demensia dan akhirnya saat memasuki usia 90an tahun 7 dari 10 lanjut usia mengalami demensia. Jika dibandingkan dengan prevalensi pada tingkat global prevalensi demensia di DI Yogyakarta jauh lebih tinggi (Suriastini, Turana, Witoelar, Supraptilah, Wicakson, \& Dwi, 2016).

Berdasarkan masalah diatas, maka diperlukan upaya untuk mengatasi masalah demensia pada lansia. Upaya yang dapat dilakukan yaitu dengan memberikan art therapy dan brain gym. Sesuai penelitian yang yang telah dilakukan oleh Wang, Qiu-Yue \& Li, Dong-Mei (2016) bahwa art therapy dapat meningkatkan perhatian dan orientasi pada pasien demensia, mengurangi gejala perilaku dan psikologsi, meningkatkan keterampilan sosial pasien dan meringankan beban keluarga atau care giver pasien demensia. Penelitian yang dilakukan oleh Chancellor, Duncan, \& Chatterjee (2014) bahwa art therapy melibatkan perhatian, memberikan kesenangan, dan meningkatkan gejala neuropsikiatri, perilaku sosial, dan harga diri pada lansia demensia. Menurut penelitian Candra, Rikayanti dan Sudiantara (2014) menyebutkan bahwa keefektifan Art therapy (terapi menggambar) dilakukan dengan waktu 45 menit, selama 7 hari sebanyak 1-2 kali sehari. Peneliti melakukan kombinasi art therapy dengan brain gym. Penelitian yang telah dilakukan oleh Cancela, Suárez, Vasconcelos, Lima, \& Ayán, (2015) bahwa brain gym mampu meningkatkan kebugaran dan tingkat kognitif pada lansia. Hal ini sejalan dengan penelitian yang dilakukan oleh Sangundo \& Sagiran (2009) bahwa brain gym mampu meningkatkan fungsi kognitif pada lansia yang mengalami demensia. Penelitian yang dilakukan oleh Retnani, Probowati dan Ratnawati (2014) bahwa lansia yang belum bisa mempertahankan fungsi intelektualnya, maka bisa mengendalikan penurunan intelektual dengan cara melakukan kegiatan yang melatih ketrampilan intelektual mereka seperti memecahkan masalah yang sederhana, tetap menggerakkan anggota tubuh secara wajar, mengenal tulisan, angka, symbol dan sebagainya. 


\section{BAHAN DAN METODE}

Jenis penelitian ini adalah penelitian ekperimen semu atau Quasi experimental. Penelitian ini menggunakan rancangan pre dan post with control group design untuk mengetahui perbedaan efektivitas art therapy dan brain gym terhadap fungsi kognitif dan intelektual lansia demensia. Penelitian dilakukan di BPSTW Yogyakarta yaitu di BPSTW Unit Abiyoso dan BPSTW Unit Budi Luhur. BPSTW Unit Abiyoso mendapatkan intervensi Art therapy sedangkan BPSTW Unit Budi Luhur mendapatkan intervensi Brain gym. Pengambilan data dilakukan pada bulan 16-29 April 2018. Populasi dalam penelitian ini adalah lansia yang mengalami demensia yang berada di BPSTW Yogyakarta sebanyak 98 lansia. Sampel dalam penelitian ini adalah lansia yang berada di BPSTW Yogyakarta dan memenuhi kriteria penelitian yakni lansia demensia yang berumur 60 tahun keatas, bersedia menjadi subjek penelitian dengan menggunakan informed consent, hadir pada saat penelitian dilakukan, dan lansia mengalami gangguan jiwa. Teknik sampling yang digunakan adalah quota sampling dengan tetap mengacu pada kriteria sampel penelitian yang berjumlah 53 responden.

Intervensi art therapy dilakukan di BPSTW Abiyoso berupa terapi menggambar yang dilakukan selama 30 menit selama 2 minggu. Peneliti melakukan art therapy dengan menggunakan media buku gambar, penggaris, pemghapus dan pensil warna selama 1 minggu. Pertemuan pertama, lansia mengekspresikan hal yang dirasakan sangat mengganggu pada masa anak-anak yang dituangkan dalam media gambar diantaranya umur satu tahun sudah dititipkan sama orang lain, takut pada ular, tidak suka makan telur asin, dll. Pertemuan kedua, lansia mengekspresikan hal yang dirasakan sangat menyenangkan pada masa anak-anak yang dituangkan dalam media gambar diantaranya bermain gobak sodor, bermain di sungai dan sawah, bermain permainan dakon, dan lainlain. Pertemuan ketiga, lansia mengekspresikan hal yang dirasakan sangat mengganggu pada masa remaja yang dituangkan dalam media gambar, diantaranya jatuh terpeleset, tidak sekolah, pernah sakit di rumah sakit, dan lain-lain. Pertemuan keempat, lansia mengekspresikan hal yang dirasakan sangat menyenangkan pada masa remaja yang dituangkan dalam media gambar, misalnya menanam padi, sering main dengan teman, waktu sekolah dan lain-lain. Pertemuan kelima, lansia mengekspresikan hal yang dirasakan sangat mengganggu pada masa dewasa yang dituangkan dalam media gambar, misalnya jatuh di kedua lututnya, tidak suka makan cabe, cek cok dengan teman, dan lain-lain. Pertemuan keenam, lansia mengekspresikan hal yang dirasakan sangat menyenangkan pada masa dewasa yang dituangkan dalam media gambar, jalan-nonton ketoprak, ikut senam, suka makan manga, dan lain-lain. Untuk pertemuan ke tujuh sampai duabelas dilakukan minggu ke dua dengan urutan yang sama.

Dalam pelaksanaan art therapy yang dilakukan di BPSTW, lansia melakukan dalam waktu 30-45 menit yang didampingi oleh petugas BPSTW. Kegiatan dilakukan di masing-masing wisma pada sore hari, setelah semua kegiatan rutin yang dilakukan lansia selesai sehingga lansia bisa fokus terhadap intervensi yang di berikan oleh peneliti. Setelah selesai menggambar, lansia menjelaskan tentang masing-masing hasil gambarnya kepada lansia lain.

Peneliti melakukan terapi brain gym kepada lansia di BPSTW Budi Luhur yang mengalami demensia yang dilakukan pada sore hari dengan waktu 20-30 menit selama 2 minggu. Peneliti mengajarkan latihan brain gym dengan melibatkan petugas BPSTW dan diikuti oleh lansia. Penelitian di lakukan bersama-sama di ruangan aula. Peneliti bersama dengan petugas BPSTW dan asisten mengajak dan mendampingi lansia untuk dapat berkumpul di aula. Pelibatan petugas BPSTW diharapkan mampu melanjutkan intervensi brain gym setelah penelitian selesai. Peneliti juga memberikan modul latihan brain gym serta poster yang ditempelkan di masing-masing wisma. Hal itu dilakukan agar lansia tetap bisa belajar menghafalkan gerakan-gerakan brain gym. Pada pertemuan kedua sampai terakhir, lansia secara bergantian akan menjadi instruktur brain gym kepada lansia lain.

Fungsi kognitif pada lansia diukur menggunakan instrument HVLT (Hopkins Verbal Learning Test), sedangkan fungsi intelektual lansia diukur menggunakan instrument SPMSQ (Short Portable Mental Status Questionaire). Analisis bivariat bertujuan untuk menganalisis dan mengidentifikasi perbedaan yang signifikan antara dua variabel. Uji statistik dianalisis dengan tingkat kemaknaan 95\% (alpha 0,05). Peneliti menggunakan uji paired t-test dan Wilcoxon signed rank test untuk mengetahui perbedaan mean sebelum dan setelah dilakukan intervensi art therapy maupun brain gym. Peneliti juga menggunakan uji Uji mann whitney untuk mengetahui perbedaan skor pada kelompok yang diberikan intervensi art therapy dan kelompok yang diberikan intervensi brain gym. 
Penelitian ini sudah lolos uji etik dan telah medapatkan surat kelayakan etik (Ethical Clearance) dari tim Komisi Etik Universitas Respati Yogyakarta.

\section{HASIL}

Tabel 1. Efektifitas pemberian intervensi brain gym terhadap fungsi kognitif dan intelektual lansia di BPSTW Yogyakarta, tahun 2018 (n=27)

\begin{tabular}{lcccc}
\hline Variabel & Mean & Median & Std. Deviation & P value 2 tailed \\
\hline Fungsi kognitif & & & & $0,000^{*}$ \\
Pre test & 7,59 & 8 & 4,449 & \\
Post test & 11 & 12 & 4,549 & $0,018^{*}$ \\
\hline Fungsi intelektual & 5,15 & 6 & 2,507 & \\
Pre test & 5,98 & 6 & 2,564 & \\
Post test & & & & \\
\hline
\end{tabular}

* Uji bivariate menggunakan SPSS dengan uji Wilcoxon signed rank test dengan nilai signifikasi $\alpha=$ 0,05

Berdasarkan tabel 1, didapatkan hasil bahwa skor fungsi kognitif lansia mengalami peningkatan setelah mendapatkan intervensi brain gym. Dari hasil pengukuran fungsi kognitif lansia dengan menggunakan HVLT (Hopskin Verbal Learning Test), terdapat peningkatan nilai mean sebesar 3,41 point. Uji bivariate menggunakan uji Wilcoxon signed rank test dengan $\mathrm{p}$ value sebesar 0,00 kurang dari alpha $(0,00<0,05)$. Terdapat perbedaan skor fungsi kognitif secara signifikan sebelum dan setelah di berikan intervensi brain gym. Sedangkan pengukuran fungsi intelektual lansia menggunakan SPMSQ, terdapat peningkatan nilai mean sebesar 0,83 . Hasil uji bivariate menggunakan Wilcoxon signed rank test dengan $\mathrm{p}$ value sebesar 0,018 . Terdapat perbedaan skor fungsi intelektual secara signifikan sebelum dan setelah di berikan intervensi brain gym.

Tabel 2. Efektifitas pemberian intervensi art therapy terhadap fungsi kognitif dan intelektual lansia di BPSTW Yogyakarta, tahun $2018 \quad(n=26)$

\begin{tabular}{lcccc}
\hline Variabel & Mean & Median & Std. Deviation & P value 2 tailed \\
\hline Fungsi kognitif & & & & \\
Pre test & 9,46 & 10,5 & 4,012 & $0,000^{*}$ \\
Post test & 12,92 & 14,5 & 5,803 & \\
\hline Fungsi intelektual & & & & $0,049^{* *}$ \\
Pre test & 5,54 & 5,50 & 2,470 & \\
Post test & 6,12 & 6,50 & 3,024 & \\
\hline
\end{tabular}

* Uji bivariate menggunakan SPSS dengan uji Wilcoxon signed rank test dengan nilai signifikasi $\alpha=$ 0,05

** Uji bivariate menggunakan SPSS dengan uji uji Paired t-test dengan nilai signifikasi $\alpha=$ 0,05

Berdasarkan tabel 2, didapatkan hasil bahwa skor fungsi kognitif lansia mengalami peningkatan setelah mendapatkan intervensi art therapy. Dari hasil pengukuran fungsi kognitif lansia dengan menggunakan HVLT (Hopskin Verbal Learning Test), terdapat peningkatan nilai mean sebesar 3,46 point. Uji bivariate menggunakan uji Wilcoxon signed rank test dengan $\mathrm{p}$ value sebesar 0,00 . Terdapat perbedaan skor fungsi kognitif secara signifikan sebelum dan setelah di berikan intervensi art therapy. Sedangkan pengukuran fungsi intelektual lansia menggunakan SPMSQ, terdapat peningkatan nilai mean sebesar 0,58. Hasil uji bivariate menggunakan Paired t test dengan $\mathrm{p}$ 
value sebesar 0,049. Terdapat perbedaan skor fungsi intelektual secara signifikan sebelum dan setelah di berikan intervensi art therapy.

Tabel 3. Perbedaan Efektifitas intervensi art therapy dan brain gym terhadap fungsi kognitif dan intelektual lansia di BPSTW Yogyakarta, tahun $2018(n=53)$

\begin{tabular}{lc}
\hline \multicolumn{1}{c}{ Variabel } & P value (2 tailed) \\
\hline Skor kognitif (pre) & $0,120^{*}$ \\
\hline Skor kognitif (post) & $0,158^{*}$ \\
\hline Skor intelektual (pre) & $0,484^{*}$ \\
\hline Skor intelektual (post) & $0,935^{*}$ \\
\hline
\end{tabular}

* Uji bivariate menggunakan SPSS dengan uji Mann Whitney dengan nilai signifikasi $\alpha=0,05$

Berdasarkan tabel 3 diatas, bahwa p-value skor kognitif sebelum dan setelah di berikan intervensi art therapy dan brain gym yaitu 0,120 dan 0,158 ( $\mathrm{p}$ value >0,05), berarti bahwa tidak ada perbedaan efektifitas intervensi art therapy dan brain gym terhadap skor fungsi kognitif pada lansia demensia. Hasil p- value skor intelektual sebelum dan setelah di berikan intervensi art therapy dan brain gym yaitu 0,484 dan 0,935 ( $\mathrm{p}$ value $>0,05$ ), berarti bahwa tidak ada perbedaan efektifitas intervensi art therapy dan brain gym terhadap skor fungsi intelektual pada lansia demensia.

\section{PEMBAHASAN}

\section{Efektifitas Art therapy terhadap fungsi kognitif dan intelektual pada lansia demensia di BPSTW Yogyakarta}

Berdasarkan hasil analisis data yang dilakukan oleh peneliti dengan menggunakan instrument HVLT (Hopkins Verbal Leraning Test), bahwa nilai kognitif lansia sebelum dan setelah dilakukan intervensi art therapy mengalami peningkatan. Terdapat peningkatan nilai mean sebesar 3,46 point. Nilai mean skor kognitif sebelum dilakukan iuntervensi art therapy sebesar 9,46 dan setelah diberikan intervensi art therapy sebesar 12,92. Namun secara kategorik, fungsi kognitif lansia demensia masih berada dalam kategori demensia karena memiliki nilai mean skor kognitif dibawah 14,5. Hasil uji bivariate menggunakan uji Wilcoxon signed rank test dudapatkan $\mathrm{p}$ value sebesar 0,00 yang berarti bahwa terdapat perbedaan skor fungsi kognitif secara signifikan sebelum dan setelah di berikan intervensi art therapy.

Hal tersebut sesuai penelitian yang yang telah dilakukan oleh Wang, Qiu-Yue \& Li, DongMei (2016) bahwa art therapy dapat meningkatkan perhatian dan orientasi pada pasien demensia, mengurangi gejala perilaku dan psikologsi, meningkatkan keterampilan sosial pasien dan meringankan beban keluarga atau care giver pasien demensia. Penelitian yang dilakukan oleh Chancellor, Duncan, \& Chatterjee (2014) bahwa art therapy melibatkan perhatian, memberikan kesenangan, dan meningkatkan gejala neuropsikiatri, perilaku sosial, dan harga diri pada lansia demensia. Art therapy merupakan terapi non farmakologi yang efektif diterapkan di tatanan institusi seperti di BPSTW karena dapat dilakukan secara bersama-sama dengan lansia lain. Adanya proses mengingat kejadian pada masa lalu sehingga mampu merangsang kemampuan otak untuk mengingat (recall) memori masa lalu. Beberapa lansia mengatakan bahwa merasa lega setelah menceritakan kejadian masa lalu dengan orang lain. Sesuai dengan penelitian yang dilakukan oleh Mimica \& Kalinic (2011) bahwa Intervensi non-farmakologis bermanfaat dalam meningkatkan gangguan perilaku yang sering muncul selama perkembangan demensia, dan kombinasi teknik dan obat nonfarmakologis lebih efektif daripada psikofarmaka saja. Dengan menggambar, lansia merasa tenang dan terjadi perbaikan terhadap perilakunya. Art therapy terbukti merupakan intervensi nonfarmakologis yang sangat baik, untuk mengurangi perilaku stres pada lansia demensia.

Berdasarkan hasil analisis data bahwa nilai intelektual lansia sebelum dan setelah dilakukan intervensi art therapy mengalami peningkatan. Terdapat peningkatan nilai mean sebesar 0,58 point. Nilai mean skor intelektual sebelum dilakukan intervensi art therapy sebesar 5,54 dan setelah 
diberikan intervensi art therapy sebesar 6,12. Namun secara kategorik, fungsi intelektual lansia demensia masih berada dalam kategori kerusakan intelektual ringan. Hasil uji bivariate menggunakan Paired $t$ test dengan $\mathrm{p}$ value sebesar 0,049. Terdapat perbedaan skor fungsi intelektual secara signifikan sebelum dan setelah di berikan intervensi art therapy.

Peneliti mengukur fungsi intelektual lansia menggunakan instrument SPMSQ (Short Portable Mental Status Questionnaire). Instrumen SPMSQ merupakan instrumen untuk orientasi, memori dalam hubungannya dengan kemampuan perawatan diri, memori jangka panjang, dan kemampuan matematis. Menurut Tamher (2009), perubahan Intelektual pada lansia yaitu berupa penurunan Intelegensi Dasar yang berarti penurunan fungsi otak bagian kanan yang antara lain berupa kesulitan dalam komunikasi nonverbal, pemecahan masalah, mengenal wajah orang, kesulitan dalam pemusatan perhatian dan konsentrasi, namun dalam bidang vocabulary (kosakata), informasi matematika, dan pengetahuan umum tetap stabil. Kemunduran pada intelektual juga cenderung mempengaruhi keterbatasan memori tertentu. Intervensi art therapy yang diberikan oleh peneliti berisi tentang kemampuan klien untuk mengingat kembali memory masa lalu baik menyenangkan atau menyedihkan mulai dari masa anak-anak sampai masa dewasa. Responden yang melakukan intervensi ini, di stimulasi untuk dapat mengingat kembali kejadian pada masa lalu.

\section{Efektifitas Brain gym terhadap fungsi kognitif dan intelektual pada lansia demensia di BPSTW Yogyakarta}

Berdasarkan hasil analisis data yang dilakukan oleh peneliti dengan menggunakan instrument HVLT (Hopkins Verbal Leraning Test), bahwa nilai kognitif lansia sebelum dan setelah dilakukan intervensi brain gym mengalami peningkatan. Terdapat peningkatan nilai mean sebesar 3,41 point. Nilai mean skor kognitif sebelum dilakukan intervensi brain gym sebesar 7,59 dan setelah diberikan intervensi brain gym sebesar 11. Namun secara kategorik, fungsi kognitif lansia demensia masih berada dalam kategori demensia karena memiliki nilai mean skor kognitif dibawah 14,5. Hasil uji bivariate menggunakan uji Wilcoxon signed rank test dudapatkan $\mathrm{p}$ value sebesar 0,00 yang berarti bahwa terdapat perbedaan skor fungsi kognitif secara signifikan sebelum dan setelah di berikan intervensi brain gym.

Penelitian yang telah dilakukan oleh Cancela, Suárez, Vasconcelos, Lima, \& Ayán, (2015) bahwa brain gym mampu meningkatkan kebugaran dan tingkat kognitif pada lansia. Hal ini sejalan dengan penelitian yang dilakukan oleh Sangundo \& Sagiran (2009) bahwa brain gym mampu meningkatkan fungsi kognitif pada lansia yang mengalami demensia. Gerakan senam otak mengaktifkan kembali hubungan saraf antara tubuh dan otak sehingga memudahkan aliran energi elektromagnetik ke seluruh tubuh. Senam otak dapat menjaga keseimbangan kinerja antara otak kanan dan kiri tetap optimal dengan memberikan stimulus perbaikan pada seratserat di corpus callosum dan beberapa struktur otak termasuk hipokampus dan amigdala sehingga dapat meningkatkan fungsi kognitif pada lansia (Yusuf, Indarwati, Jayanto, 2010).

Memori jangka pendek (short term memory) merupakan kemampuan daya ingat selama 30 menit terakhir dan beberapa minggu terakhir. Instumen HVLT yang digunakan oleh peneliti digunakan untuk mengukur memori jangka pendek. Hal ini sesuai dengan penelitian yang telah dilakukan oleh Triestuning (2017) bahwa pemberian brain gym dapat meningkatkan memori (ingatan) jangka pendek lansia karena dengan gerakan senam otak dapat merangsang integrasi kerja bagian otak kanan dan kiri untuk menghasilkan koordinasi fungsi otak yang harmonis sehingga dapat menghasilkan kemampuan memori, kemampuan koordinasi tubuh, kemampuan motoric halus dan kasar.

Berdasarkan hasil analisis data bahwa nilai intelektual lansia sebelum dan setelah dilakukan intervensi brain mengalami peningkatan. Terdapat peningkatan nilai mean sebesar 0,83 point. Nilai mean skor intelektual sebelum dilakukan intervensi art therapy sebesar 5,15 dan setelah diberikan intervensi brain gym sebesar 5,98. Namun secara kategorik, fungsi intelektual lansia demensia masih berada dalam kategori kerusakan intelektual ringan. Hasil uji bivariate menggunakan Wilcoxon signed rank test dengan $\mathrm{p}$ value sebesar 0,018 . Terdapat perbedaan skor fungsi intelektual secara signifikan sebelum dan setelah di berikan intervensi brain gym.

Pemberian intervensi brain gym dilakukan secara terus menerus selama 2 minggu. Lansia juga belajar dari modul dan poster yang telah diberikan oleh peneliti. Hal tersebut sesuai dengan 
smeltzer (2002) bahwa Smeltzer menjelaskan bahwa untuk mempermudah fungsi belajar dan pemahaman lansia, perawat lansia harus dapat mendorong penggunaan intelegensia lansia secara terus-menerus, menghubungkan informasi baru dengan informasi yang sudah dikenal, menggunakan alat bantu visual, auditori, dan alat bantu indera lain,

\section{Perbedaan Efektifitas Art therapy dan Brain gym terhadap fungsi kognitif dan intelektual pada lansia demensia di BPSTW Yogyakarta}

Berdasarkan hasil analisis menggunakan uji Mann Whitney bahwa p value skor kognitif dan intelektual setelah di berikan intervensi art therapy dan brain memiliki nilai 0,158 dan 0,935 yang berarti bahwa tidak ada perbedaan yang signifikan antara intervensi art therapy dan brain gym terhadap fungsi kognitif dan intelektual pada lansia demensia. Kedua intervensi tersebut secara statistik sama-sama mampu meningkatkan skor kognitif dan intelektual. Namun secara numerik, Intervensi Art therapy mampu meningkatkan skor kognitif lebih tinggi dibandingkan brain gym dengan selisih 0,05 point. Art therapy juga memiliki skor lebih tinggi dalam meningkatkan fungsi intelektual lansia di bandingkan brain gym dengan selisih 0,031 point.

Hasil penelitian ini sesuai dengan yang dilakukan oleh Erwanto \& Amigo (2017) bahwa pemberian art therapy dilanjutkan dengan brain gym selama 2 minggu mampu meningkatkan fungsi kognitif pada lansia. Pemberian intervensi art therapy mampu meningkatkan skor fungsi kognitif dan intelektual lansia demensia lebih tinggi dibandingkan brain gym dikarenakan lansia berusaha menggunakan mengingat kembali kejadian dari masa anak-anak sampai dewasa yang dituangkan dalam gambar, kemudian lansia saling menceritakan pengalamannya dengan lansia yang lain. Hal ini dapat menstimulasi memori lansia, sesuai dengan penelitian yang telah dilakukan oleh Kushariyadi (2013) bahwa lansia yang diberikan stimulasi kognitif mengalami peningkatan skor kognitif yang diukur dengan menggunakan instrument MMSE (Mini mental State Examination). Fungsi kognitif yang meningkat diantaranya kemampuan orientasi, perhatian dan kalkulasi, kemampuan mengingat kembali dan bahasa. Berbeda dengan brain gym, Lansia hanya melakukan gerakan senam brain gym dan tidak mencoba menggali ingatan masa lalunya.

\section{KESIMPULAN}

Berdasarkan penelitian diatas dapat diambil kesimpulan bahwa kedua intervensi Art therapy dan Brain gym mampu meningkatkan fungsi kognitif dan intelektual pada lansia demensia secara signifikan. Terdapat perbedaan skor kognitif dan intelektual pada lansia demensia sebelum dan setelah di berikan intervensi Art therapy dan Brain gym. Diharapkan hasil penelitian ini bisa diaplikasikan oleh petugas panti atau perawat di tatanan institusi pelayanan lansia agar fungsi kognitif dan intelektual pada lansia tidak mengalami kemunduran secara progresif sehingga kualitas hidup lansia tidak mengalami kemunduran

\section{DAFTAR PUSTAKA}

Alzheimer Disease International. (2008). Piagam Global Penyakit Alheimer. London: Alzheimer Disease International

Cancela, J. M., Suárez, M. V., Vasconcelos, J. Lima, A., \& Ayán, C. (2015). Efficacy of Brain gym Training on the Cognitive Performance and Fitness Level of Active Older Adults: A Preliminary Study. Journal of Aging and Physical Activity.

Candra, I. W., Rikayanti, N. K., \& Sudiantara, I. K. (2013). Terapi okupasi menggambar terhadap perubahan halusinasi pada pasien Skizofrenia. Politeknik Kesehatan Denpasar.

Chancellor, B., Duncan, A., \& Chatterjee, A. (2014). Art therapy for Alzheimer's disease and other dementias. Pubmed: J Alzheimers Dis. 2014;39(1):1-11. doi: 10.3233/JAD-131295.

Darmojo, B. (2011). Buku Ajar Geriatic (Ilmu Kesehatan Lanjut Usia) edisi ke - 4.Jakarta: FKUI. 
Erwanto, R., \& Amigo, T. A. E. (2017). Efektifitas Art therapy Dan Brain gym Terhadap Fungsi Kognitif Lansia. Jurnal poltekkes Ternate VOL. 10 No. 2 November 2017.

Kemenkes. (2015). Penanggulangan Penyakit Alzheimer dan Demensia lainnya: Menuju Lanjut Usia Sehat Dan Produktif. Jakarta: Kemenkes.

Kementerian Kesehatan Republik Indonesia. (2016). Situasi Lanjut Usia (LANSIA) di Indonesia. Jakarta: Pusat Data dan Informasi Kementerian Kesehatan RI.

Kushariyadi.. (2013). Intervensi (Stimulasi Memori) meningkatkan fungsi kognitif lansia. Jurnal Ners Vol. 8 No. 2 Oktober $2013: 317-329$.

Maurer, F. A., \& Smith, C. M. (2005). Community/Public Health Nursing Practice: Health for Families and Populations. Philadelphia: Elsevier Saunders.

Mimica, N., \& Kalinic, D. (2011). Art therapy May Be Benefitial For Reducing Stress Related Behaviours In People With Dementia - Case Report. Psychiatria Danubina, 2011; Vol. 23, No. 1, pp 125-128.

Retnani, Probowati \& Ratnawati. (2014). Gambaran Fungsi Intelektual Lanjut Usia Di Posyandu Flamboyan Desa Bandung Kecamatan Diwek Kabupaten Jombang. Jurnal Metabolisme Vol. 3 No. 2.

Sangundo \& Sagiran. (2009). Pengaruh Brain gym terhadap Fungsi Kognitif pada Usia Lanjut. Mutiara Medika. Edisi Khusus Vol. 9 No. 2: 86 - 94, Oktober 2009.

Smeltzer, Suzanne, C. \& Brenda, G. B. (2002). Buku Ajar Keperawatan Medikal-Bedah, Brunner \& Suddarth, Edisi 8. Jakarta: Penerbit EGC.

Stanhope, M., \& Lancaster, J. (2004). Community \& public health nursing (six ed.). St. Louis, Missouri: Mosby.

Suriastini, Turana, Y., Witoelar, F., Supraptilah, B., Wicakson, T. Y., \& Dwi, E. (2016). Angka Prevalensi Demensia: Perlu Perhatian Kita Semua. Policy Brief. Yogyakarta : Survey meter.

Tamher. (2009). Kesehatan Usia Lanjut dengan Pendekatan Asuhan Keperawatan. Jakarta: Salemba Medika.

Triestuning, E. (2017). Pengaruh Senam Otak terhadap peningkatan short term memory pada lansia. Jurnal Nurse and health Vol 7, Issue 1, January-June 20.

United Nations Department of Economic and Social Affairs/ Population Division. (2015). Word Population Prospects Key Finding and Advance Tables. United Nation New York.

Wang, Qiu-Yue \& Li, Dong-Mei. (2016). Advances in art therapy for patients with dementia. Chinese Nursing Research. Volume 3, Issue 3, September 2016, Pages 105-10.

World Alzheimer Report. (2012). Overcoming the stigma of dementia. London : Alzheimer's Disease International.

Yusuf, A., Indarwati, R., \& Jayanto, A. D. (2010). Brain gym Improves Cognitive Function for Elderly. Jurnal Ners Vol. 5 No. 1 April 2010: 79-86. 